\title{
FinTech in Taiwan: a case study of a Bank's strategic planning for an investment in a FinTech company
}

\author{
Jui-Long Hung ${ }^{1 *}$ (D) and Binjie Luo ${ }^{2}$
}

\author{
* Correspondence: \\ andyhung@boisestate.edu \\ ${ }^{1}$ Boise State University, Boise, USA \\ Full list of author information is \\ available at the end of the article
}

\begin{abstract}
Introduction: Since 2015 is the year of FinTech in Taiwan, it is worth investigating the challenges that emerged when banks were encouraged to invest in FinTech companies for collaboration. This study aims to identify the strategic considerations in the process of searching for FinTech investment targets.

Case description: This study used a case study investigation of a top-5 bank in Taiwan. The major data sources include the meeting notes of the FinTech investment task force and interviews with the team members. Co-opetition theory was adopted as the theoretical framework and interview questions were derived from the PARTS strategies in co-petition theory. The results relate to: (1) the strategic goals of FinTech investment, (2) the added value from FinTech companies, (3) criteria in selecting candidates in the same FinTech area, (4) choosing to work as either a cooperator or a competitor, and (5) barriers from policies and regulations.
\end{abstract}

Discussion and evaluation: This study has several findings: (1) regulations and policies shape FinTech's development; (2) banks, technology companies, and customers are not "FinTech ready;" (3) Compare top-down with bottom up strategies;

(4) banks and FinTech companies have complex relationships; (5) it is unlikely that Taiwan will produce FinTech disruptors in the near future.

Conclusion: The findings and discussion can benefit researchers and administrators in finance-related industries. More studies are desired to observe long-term development in terms of how companies collaborate or compete in specific FinTech areas.

Keywords: FinTech, Taiwan FinTech Industry, Investment in FinTech, Bank 3.0, Taiwan bank industry, Co-opetition Theory, PARTS

\section{Background}

In January 2015, the Finance Supervisory Commission in Taiwan (TFSB) announced the "Creating the Digital Finance Environment 3.0 Project" that aims to relax restrictions on online banking, especially in online applications (Financial Supervisory Committee 2015a, 2015b, 2015c). The first wave required all banks to offer the online financial services listed in Table 1 by the end of 2015 (Financial Supervisory Committee 2015a). The policy was inspired by a book titled "Bank 3.0: Why Banking Is No Longer Somewhere You Go but Something You Do" (King 2012), which predicted the disappearance of most bank branches in the near future and that most financial services offered in 
Table 1 First Wave of Digital Finance Environment 3.0 Project

\begin{tabular}{lll}
\hline Service Item & & Target Customer \\
\hline Deposit & Closing a deposit account & Current deposit account holder \\
& Opening a predesignated account & Current deposit account holder \\
Credit evaluation & Approving payment transfer application via fax & Current deposit account holder \\
Credit card & Applying for new credit card & Current deposit account holder \\
& or loan account holder \\
& Applying for microfinance & Current deposit account or \\
Wealth management & Opplying for installment & existing credit card holder \\
& Compleng a trust account & Current credit card holder \\
& Completing customer risk tolerance survey & Current credit card holder \\
& Accepting or terminating agreement of trust & Current deposit account holder \\
product recommendation & Current deposit account holder \\
& Filling out joint marketing agreement & Current deposit account holder \\
\hline
\end{tabular}

traditional branches will be transferred to online environments (King 2012). A bank is no longer the only center for all financial services. E-commerce or telecommunication companies could create new forms of financial services using technology to replace the role of banks. To decrease the impacts of the coming trend, the TFSB mailed an official order to all banks in Taiwan asking all domestic banks to propose a strategic plan to adjust the structure of human resources via training or career planning to meet the changes in human resource demands in the future.

The coming trend of FinTech is a major cause of concern for the TFSB. This is because "FinTech," a combination of "Finance" and "Technology" that refers to the combination of both domains that will lead innovative financial services to shift away from an in-house approach to relying on external providers to deliver online and mobile solutions in a timely manner. On the one hand, the disruptive innovation can initiate new businesses and bring new job opportunities. On the other hand, it damages the basis of the banking industry, which is an important stable socio-economic foundation for nearly all countries. FinTech companies can choose to be the "disruptors"-players that enter the market to compete against existing financial institutions, or "collaborators"-those primarily targeting financial institutions as customers. Banks not only have to deal with challenges from potential disruptors, but also to collaborate with technology companies to win the competition.

A recent analysis indicates that the global FinTech investment growth continues in 2016, driven by Europe and Asia (Accenture 2016). Global investment in FinTech ventures in the first quarter of 2016 reached $\$ 5.3$ billion, a $67 \%$ increase over the same period last year, and the proportion of investments going to FinTech companies in Europe and Asia-Pacific nearly doubled to 62\% (Venture Scanner 2016). However, the report shows that collaborative versus disruptive FinTech ventures have different investment patterns in different areas. Overall, funding for collaborative FinTech ventures, which accounted for 38\% of all FinTech investment in 2010, grew to $44 \%$ of funding in 2015. In North America, the proportion of funding for collaborative 
FinTech rose from 40 to $60 \%$ and in Asia-Pacific, it increased from 7 to $16 \%$. In Europe, however, the reverse trend was true. Funding for "disruptors" there rose from 62\% of all FinTech investments in 2010 to 86\% in 2015 (Venture Scanner 2016).

Since 2015 is the year of FinTech in Taiwan, it is worth investigating the challenges that emerged when banks were encouraged to invest in FinTech companies for collaboration. The single case study approach is appropriate because it provides researchers with an in-depth look at the context, organizational relationships, knowledge, and experiences of the target case (Benbasat et al. 1987; Cavaye 1996; Miles and Huberman 1994). This study adopts the co-opetition theory (Brandenburger and Nalebuff 1996) as the theoretical foundation guiding the investigation. The results can reflect a bank's strategic planning in response to the era of digital finance. The findings and discussion can benefit researchers and administrators in finance-related industries.

\section{Literature review}

FinTech

Wikipedia defines FinTech as "an economic industry composed of companies that use technology to make financial systems more efficient" (Wikipedia nd). FinTech weekly (nd) defines FinTech as "a line of business based on using software to provide financial services.” The TFSB defines FinTech companies as belonging to one of the following categories (Financial Supervisory Committee 2015c):

- Using information or network technologies to aid the business development of financial institutions to gather, process, analyze, or supply data (e.g., big data, cloud computing, machine learning, etc.).

- Using information or network technologies to improve the efficiency or security of financial services or operating processes (e.g., mobile payment, automated investment advisor, blockchain technology, biometrics, etc.).

- Designing or developing other digital or innovative financial services based on information or technology.

As mentioned earlier, aggregated global investment in FinTech ventures in the first quarter of 2016 reached $\$ 5.3$ billion, a 67\% increase over the same period last year (Accenture 2016). Based on Venture Scanner's report for the $4^{\text {th }}$ quarter of 2016 (Venture Scanner 2016), FinTech companies can be classified into the following categories:

- Banking Infrastructure (114 startups, 1.5B funding)

- Business Lending (181 startups, 9.8B total funding)

- Consumer and Commercial Banking (66 startups, 1.5 B total funding)

- Consumer Lending (264 startups, 16.7B total funding)

- Consumer Payments (182 startups, 9.5B total funding)

- Crowdfunding (68 startups, $436 \mathrm{M}$ total funding)

- Equity Financing (137 startups, $738 \mathrm{M}$ total funding)

- Financial Research and Data (79 startups, 824 M total funding)

- Financial Transaction Security (101 startups, 1.6B total funding)

- Institutional Investing (142 startups, $781 \mathrm{M}$ total funding) 
- International Money Transfer (59 startups, 1.5B total funding)

- Payments Backend and Infrastructure (181 startups, 10.4B total funding)

- Personal Finance (194 startups, 2.7B total funding)

- Point of Sale Payments (164 startups, 7.6B total funding)

- Retail Investing (150 startups, 1.6B total funding)

- Small and Medium Business (SMB) Tools (183 startups, 7.3B total funding)

Among these categories, Consumer Lending, Personal Finance, and SMB Tools attracted the most startups, and Consumer Lending, Payment Backend, Banking Infrastructure, and Business Lending attracted the most funding. Figure 1 shows the leading companies in some of these categories (Venture Scanner 2016).

The report aggregated data for North American, Europe, and China. When comparing actual startup and total funding numbers in Venture Scanner's report with the TFSB's FinTech definition, the TFSB's blueprint differs from the actual situation in other countries.

\section{FinTech in Taiwan}

The TFSB declared 2015 as the year of FinTech by announcing a series of actions to promote its development in Taiwan. First, all domestic banks must offer twelve online financial services by the end of 2015 (Financial Supervisory Commission 2015a). Second, the TSFB announced eleven big data application projects, including government open data (after de-identification) in real estate credit evaluation, transaction data in the stock market, personal credit card transactions, and fraud statistics, and over 900 other finance-related datasets (Data.Gov.Tw 2015). Third, the banks' shareholding ratio was relaxed from 5 to 100\% for FinTech company investments (Financial Supervisory Committee 2015c). Fourth, the TSFB set up the FinTech office, promotion funds, and a startup base (Financial Supervisory Committee 2016a). Finally, the TSFB published a

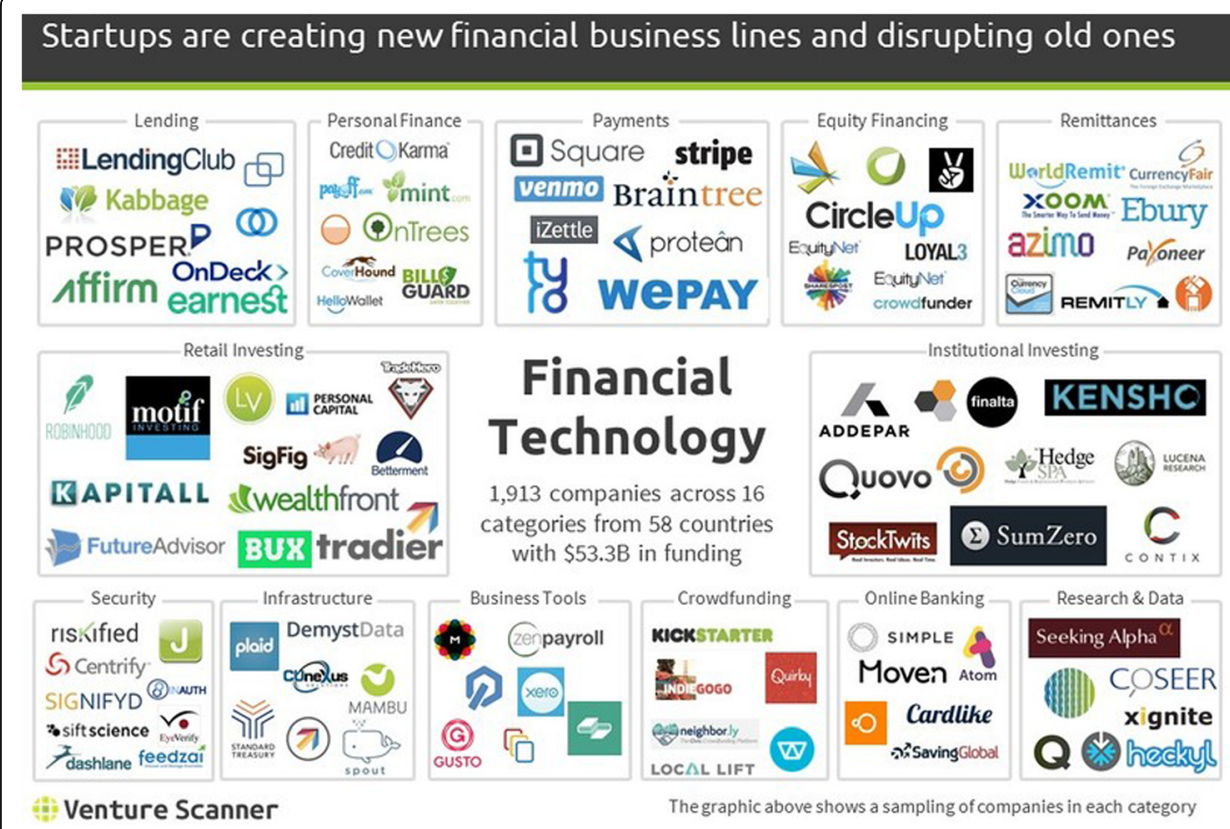

Fig. 1 Leading FinTech Companies 
FinTech white paper in 2016 (Financial Supervisory Committee 2016a). Taiwan's government aims to attract 5 billion TWD in total funding and at least 30 startups.

Among these actions, some are regulations that allow banks, insurers, or other financerelated companies to operate the digital finance businesses listed in Table 2 (Financial Supervisory Committee 2016a). Among these regulations, the "Regulations on Bank and Financial Holding Company Investments in FinTech Companies" (Financial Supervisory Committee 2015c) allows bank and financial holding companies to invest in FinTech companies and own 100\% of the shares. The other regulation, "The Regulation on Information Services and Finance Technology Industries Determined by the Competent Authority as Finance-related Industries" (Financial Supervisory Committee 2015d) further defines the scope of FinTech companies in which banks and financial holding companies can invest. Appendix A provides a detailed summary of these two regulations.

The TFSB's FinTech Development Strategy White Paper (Financial Supervisory Committee 2016c) outlines a strategic framework identifying the following major development dimensions (see Fig. 2): payment, insurance, loans, crowdfunding, investment management, and market supply (Financial Supervisory Committee 2016c).

\section{Co-opetition theory}

Co-opetition describes a strategic framework that enables organizations to classify players within their industry (Brandenburger and Nalebuff 1996). The model adopts knowledge in game theory to observe and explain the behaviors of different kinds of stakeholders within the same industry and beyond.

Table 2 Policies and Regulations to Supervise the Development of Digital Finance

\begin{tabular}{|c|c|c|c|c|}
\hline Date & Title & Purpose & Unit & Target industry \\
\hline 1999.5 & $\begin{array}{l}\text { Contract template for personal } \\
\text { computer and internet banking }\end{array}$ & $\begin{array}{l}\text { Allow banks to offer online } \\
\text { banking business }\end{array}$ & $\begin{array}{l}\text { Ministry of } \\
\text { Finance }\end{array}$ & Banking \\
\hline 2014.1 & $\begin{array}{l}\text { Regulations governing the } \\
\text { conduct of equity crowdfunding } \\
\text { by securities firms }\end{array}$ & $\begin{array}{l}\text { Allow securities firms to run } \\
\text { equity crowdfunding }\end{array}$ & $\begin{array}{l}\text { Taipei } \\
\text { Exchange }\end{array}$ & Crowdfunding \\
\hline 2014.8 & $\begin{array}{l}\text { Regulations governing the } \\
\text { conduct of online insurance } \\
\text { by insurance firms }\end{array}$ & $\begin{array}{l}\text { Allow insurance firms to offer } \\
\text { online insurance }\end{array}$ & TFSB & Insurance \\
\hline 2015.4 & $\begin{array}{l}\text { Regulations governing the } \\
\text { conduct of equity crowdfunding } \\
\text { by securities firms }\end{array}$ & $\begin{array}{l}\text { Allow securities firms to offer } \\
\text { equity crowdfunding }\end{array}$ & TFSB & Crowdfunding \\
\hline 2015.5 & $\begin{array}{l}\text { The Act Governing Electronic } \\
\text { Payment Institutions }\end{array}$ & $\begin{array}{l}\text { Allow banks and non-financial } \\
\text { companies with third-party } \\
\text { payment licenses to offer } \\
\text { e-payment business }\end{array}$ & TFSB & E-payment \\
\hline 2015.6 & $\begin{array}{l}\text { Rename "Regulations Governing } \\
\text { the Conduct of Online Insurance } \\
\text { by Insurance Firms" as "Regulations } \\
\text { Governing the Conduct of } \\
\text { E-commerce by Insurance Firms }\end{array}$ & $\begin{array}{l}\text { Relax some regulations issued } \\
\text { in } 2014.8\end{array}$ & TFSB & Insurance \\
\hline 2015.8 & $\begin{array}{l}\text { Regulations of bank and financial } \\
\text { holding company investing } \\
\text { FinTech firms }\end{array}$ & $\begin{array}{l}\text { Allow banks and financial holding } \\
\text { firms to invest in FinTech firms } \\
\text { and increase the shareholding } \\
\text { ratio }\end{array}$ & TFSB & $\begin{array}{l}\text { Banking, insurance, } \\
\text { and related FinTech } \\
\text { companies }\end{array}$ \\
\hline 2015.9 & $\begin{array}{l}\text { Regulations on Information } \\
\text { Services and Finance Technology } \\
\text { Industries Determined by the } \\
\text { Competent Authority as } \\
\text { Finance-Related Industry }\end{array}$ & $\begin{array}{l}\text { Define information service } \\
\text { industry and finance technology } \\
\text { industry }\end{array}$ & TFSB & $\begin{array}{l}\text { Banks, insurance, } \\
\text { and related } \\
\text { FinTech companies }\end{array}$ \\
\hline
\end{tabular}




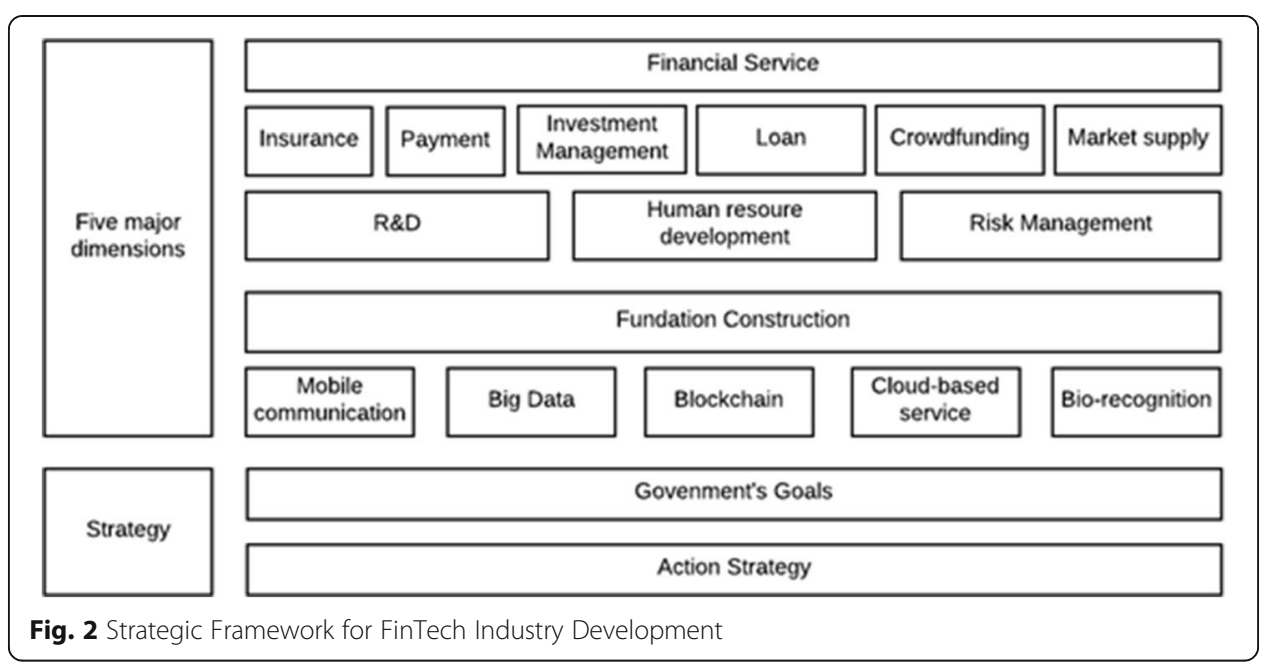

Bradenburger and Nalebuff (1996) argued that cooperation and competition exist and are desirable in every industry (Levinson and Asahi 1995). When all players focus on market growth, then they must cooperate to increase the benefits to all players (Hill and Lynn 2003). At the same time, competition distributes the benefits earned by individual players depending on their market shares. The theory provides a framework to observe how interactions between players and their choices lead to different outcomes or end states of the game. In addition, it helps administrators and researchers to identify and explain the underlying mechanisms in a firm's environment, and how the firm can change these mechanisms to their advantage.

"Value Net" is the core concept in co-opetition theory. The theory has four types of players:

- Customers: Parties to which the company directs its products and services. In return, money goes from the customers to the company.

- Suppliers: Parties who provide resources to the company. In return, money goes from the company to the suppliers.

- Competitors: The definition depends on perspective:

- Customer perspective: "A player is your competitor if customers value your product less when they have the other player's product than when they have your product by itself." Your product behaves as a substitute for a competitor's product-your increase in market share will directly decrease your competitor's share.

- Supplier perspective: "A player is your competitor if it is less attractive for a supplier to provide resources to you when it is also supplying the other player than when it is supplying you alone." All firms compete with other organizations for resources in quantity, quality, and price.

- Complementors: The definition also depends on the following perspectives:

- Customer perspective: "A player is your complementor if customers value your product more when they have the other player's product than when they have your product by itself." Complementors are the inverse of a competitor because the demand for their products will increase the demand for your product.

- Supplier perspective: "A player is your complementor if it is more attractive for a supplier to provide resources to you when it is also supplying the other player 
than when it is supplying you alone." When a market is small, it is difficult to get resources delivered by guessing. When the market increases, suppliers begin to adjust their offerings and make purchasing efforts easier for all acquiring firms.

Importantly, a single player can have more than one role; a player can be both a competitor and complementor simultaneously. The market players can cooperate on the "invisible" logistics side (e.g. develop common standards or return channels) and compete on the "visible" market share side.

The authors further proposed five dimensions (PARTS) to identify strategies that change the game, to a player's own advantage.

- Players: Players can use the Value Net to identify and categorize the current players in the game. A company can examine all players in the value net and determine the roles of individual players (customers, suppliers, complementors, and competitors). Bringing more players into the game can have positive effects on a company (e.g. increasing suppliers can decrease costs; extra complementors increase the value of a company's product; and a competitor can be brought in to give customers the feeling that they have choice.).

- Added value: Added value is an indicator to estimate benefits that individual players obtain from the value net. A company can identify its added value from the other players' point of view and take action to increase this added value in order to increase profitability (e.g., a company can offer a loyalty program to enhance customer loyalty or attract more complementors to the value net to increase its own added value).

- Rules: In every business, many written and unwritten rules apply. Rules can be governmental rules, contracts with suppliers, contracts with customers, and general market rules. Although many rules cannot be changed (such as governmental rules), contracts provide opportunities to change the rules on a smaller scale.

- Tactics: Tactics are defined as "actions that players take to shape the perceptions of other players." Brandenburger and Nalebuff argue that players always take rational actions in light of that player's perception of reality. A company can influence other players' perceptions and actions by deliberately sending out certain signals. It is necessary, however, to be aware of these perceptions to be able to influence them.

- Scope: In most cases, a game is not isolated, but linked to other games via its players. A firm can extend its business to other games when it adds value to the other game and increase its profitability. On the other hand, a firm can deliberately keep two games separate when linking the games would cannibalize its traditional business. Linking and de-linking games can occur by recognizing complementary markets, via special clauses in contracts, or by influencing the perceptions of other players.

\section{Case description}

This research conducts a case study to identify the strategic considerations in the process of investing in a FinTech company. The investigation target is a top-5 bank in Taiwan. The major data sources include the meeting notes of the FinTech investment task force and interviews with the team members. Derived from the PARTS strategies, the interview questions include: 


\begin{tabular}{l}
\hline Questions \\
What are the strategic goals when searching for potential FinTech candidates? \\
What is the added value(s) from FinTech candidates? \\
When facing competition from other banks or FinTech companies, what is T bank's strategy \\
(as a cooperator or a competitor)? \\
When selecting candidates in the same FinTech area, what are the major criteria? \\
Is there any plan to cooperate with competitors or complementors? \\
Are there any barriers from Government policies and regulations?
\end{tabular}

\section{Banking industry in Taiwan}

The banking industry in Taiwan is worth trillions of TWD and is highly protected and regulated by the government. It accounts for both $6.56 \%$ of GDP and $7.4 \%$ of all jobs in Taiwan. As of June 2016, Taiwan had 39 domestic banks with 3,433 domestic branches and 464 overseas branches or representative offices (see Table 3). The data indicate that you can find a bank branch every 3.7 and an ATM every $1.32 \mathrm{~km}^{2}$ on average. For a small island with only 23 million people, the banking industry is an extremely highly competitive market. Overall, the development of Taiwan's banking industry can be divided into three stages (Chiu 2011):

- 1949-1960 (the embryonic period): The loan market was established.

- 1961-1989 (the development period): The stock market, bond market, and foreign exchange market emerged.

- 1990-2012 (the consolidation period): An important period of liberalization and internationalization for the banking industry, with key deregulation including (1) allowing foreign banks to set up branches, allowing the establishment of new commercial banks, allowing the establishment of financial folding corporations, and allowing the privatization of public sector banks, etc.

To address the coming trend of digitalization in finance, the TFSB proactively announced a series of deregulations after 2014 to encourage financial innovation. Therefore, we might call 2014 the beginning of the fourth stage-the innovation period.

\section{Policy and regulatory barriers}

In Taiwan, the bank industry is highly protected and regulated; banks are prohibited from engaging in any business that does not have related policies or regulations.

Table 3 Head Offices and Branches of Financial Institutions in Taiwan (End of June 2016)

\begin{tabular}{llll}
\hline & Head Offices & Domestic Branches & Overseas Offices/Branches \\
\hline Domestic banks & 39 & 3,433 & 464 \\
Foreign bank branches & 27 & 37 & NA \\
Chinese bank branches & 3 & 3 & NA \\
The Postal Savings System & 1 & 1,320 & - \\
Credit cooperation & 23 & 259 & - \\
Credit departments of farmers' association & 282 & 823 & - \\
Credit departments of fishermen's association & 28 & 43 & - \\
Total & 402 & 5,918 & 464 \\
\hline
\end{tabular}


Therefore, when the government requested that all banks engage in innovation, they were not sure what to do at first. In addition, there are too many limitations or regulations for new startups. For example, the minimum capital for a new startup to apply for a third-party payment license is ten million US dollars. Additionally, FinTech companies cannot manufacture hardware and must derive more than $51 \%$ of their annual operating costs or operating revenue from financial enterprises (including financial holding companies, banks, securities firms, insurance companies, and their subsidiaries) (Appendix A). Regulations also make it difficult for foreign FinTech companies, such as P2P lenders, to enter Taiwan's market.

\section{Case study bank}

The target bank ( $\mathrm{T}$ bank) is under a financial holding corporation and ranked as one of the top 250 banks worldwide and among the top 5 in Taiwan. It has 190 branches, 34 overseas branches/representative offices, and over 5,000 domestic employees (Financial Supervisory Committee 2016b). Table 4 compares T bank with other domestic banks in major business areas (Financial Supervisory Committee 2016b).

Overall, T bank's strength is in Corporate Finance, especially in SME loans. Compared to the other top-tier commercial banks, $\mathrm{T}$ bank's personal finance business is a weakness. In 2015, T bank renamed the division of electronic finance as the division of digital banking to declare its ambitions to develop digital banking, including online banking, electronic payment, FinTech, and big data analytics. The Chairman of $\mathrm{T}$ bank aims to cultivate personal finance as another star business by means of FinTech and big data analytics. Therefore, the bank established the FinTech, Artificial Intelligence, Blockchain, and Maker Base task forces to search for the best solution providers or startups on the market. The team members include supervisors in the divisions of digital banking, information technology, personal finance, corporate finance, venture capital, foreign exchange markets, and compliments and legislative. These groups are led by two vice presidents and report to the President and Chairman directly. After over 7 months of effort, $\mathrm{T}$ bank identified the most appropriate target and completed their first investment in 2016. The task force continues to look for other suitable candidates. The next section describes the bank's process for FinTech investment by research question.

Table $4 \mathrm{~T}$ bank Compared to all Other Domestic Banks in Taiwan

\begin{tabular}{lc}
\hline Statistical indicators & Rankings \\
\hline Loans to SMEs & $1^{\text {st }}$ \\
Active credit cards & $11^{\text {th }}$ \\
Profit before tax & $4^{\text {th }}$ \\
Equities & $5^{\text {th }}$ \\
Assets & $7^{\text {th }}$ \\
Deposits & $8^{\text {th }}$ \\
Total loans & $7^{\text {th }}$ \\
Number of domestic branches & $2^{\text {nd }}$ \\
Number of overseas branches & $2^{\text {nd }}$ \\
\hline
\end{tabular}




\section{The strategic goals of FinTech investment}

Signing purchase contract with external technology vendors is very common for banks in Taiwan. However, looking for a complementor as a partner is totally a different story. It was therefore a long exploration process for $\mathrm{T}$ bank to determine the following strategic goals:

- Look for a strategic partner rather than targeting ROI only

- Look for a technology company that can co-develop unique financial services with T bank's employees

- Look for new startups or small companies with innovative expertise.

\section{Added value from FinTech companies}

The task force started with a quick survey of the list of current vendors, FinTechrelated reports or contests, and recommendations from internal and external channels to compile a list that contained 36 FinTech or FinTech-like companies (Table 5). They then examined and discussed each company in the first round of screening and selected 16 for on-site visits.

Below describe insights from the task force by FinTech categories.

\section{- Payment}

Fintech companies in the payment category can be divided into two types: Third-party payment and point of sale payment. The third-party payment companies attracted all banks' attentions in 2015 because these companies will offer services in online, offline, and online-to-offline environments. In May 2015, the TFSB announced "The Act Governing Electronic Payment Institutions" to supervise third-party payment institutions. The act allows banks and nonfinancial companies to apply for third-party payment licenses. Five non-financial companies were approved in 2015 and 2016, and each of these companies has third-party payments as their core business, similar to PayPal. In addition, 10 banks (including $\mathrm{T}$ bank) and 12 e-commerce companies can also provide third-party payments, though this is not their core business. E-payment services are already up and running at all 10 banks, but none of the five third-party companies can offer their services until 2017. These third-payment payment

Table 5 Candidate and Visited FinTech companies

\begin{tabular}{lll}
\hline Category & Total companies & Visited companies \\
\hline Financial transaction security & 3 & 1 \\
Big data analytics & 5 & 3 \\
Banking infrastructure & 4 & 0 \\
System integration & 7 & 0 \\
E-payments & 6 & 4 \\
Point of sale payments & 4 & 2 \\
E-commerce & 3 & 2 \\
Internet of Things (loT) & 2 & 2 \\
Blockchain & 2 & 2 \\
\hline
\end{tabular}


companies are very welcome bank's investment in order to form a stronger alliance. Therefore, they limit the shareholding percentage to $5-10 \%$, in order to have more bank partners. Although the third-party payment attracted many attentions in the beginning, banks predict only one or two companies will survive due to the low profit margin. Point of sale payment is the other type of payment companies whose major customers are physical retailers. These companies mainly provide POS systems to retailers. In the past, credit card readers and POS systems are different devices and a store usually needs to prepare at four credit card readers, one pre-paid card reader, and one POS system. Due to the integration of hardware (all-in-one card reader with cloudbased POS functions) and software (integrated payment API), the all-in-one smart POS system can satisfy assorted payment needs from retailer stores. In addition, the all-in-one smart POS system can accept all kinds of payment tools, including cash, credit card, pre-paid card, gift card, and other payment types via TSM, HCE, TSP, and QR Code technologies. A well-known POS company became $\mathrm{T}$ bank's first FinTech investment target. More details will be introduced later.

- Banking infrastructure and system integration The task force filtered out technology/solution providers because they felt that these companies concentrate only on their current business and are not ready for a higher-level challenge. Therefore, they selected none of companies in the banking infrastructure and system integration for online-site visits.

- P2P Loan

TFSB tended not to set up any regulations on P2P lending (Financial Supervisory Committee 2016d). In addition, TFSB encourages banks to collaborate with P2P companies on the lending business. Right now there are two P2P companies on the market (https://www.lend.com.tw and https://nb.com.tw/). Although no matter personal loan and corporate loan are not hard to be approved by banks at all, many banks, including $\mathrm{T}$ bank, are preparing to set up their own online lending platform instead of collaborating with P2P companies. For example, SinoPac bank's bidmoney platform (https://bidmoney.sinopac.com) is the first and the only P2P platform from bank. It will be expected more similar platforms will appear in these 2 years.

- Big data analytics

Big data analytics companies are hard to complete with large analytics companies, like SAS, IBM, and TaraData. Therefore, the local big data analytics companies all focus on the techniques of Chinese text mining. Chinese might be the hardest language to perform Natural Language Processing, due to its unique characteristics. Due to bank's data contains sensitive personal information, $\mathrm{T}$ bank is more interested in buying or cultivating its own analytics team. These local analytics companies can be solution providers of intelligent automatic customer services and sell their products to all banks. They are not interested in becoming a specific bank exclusive company.

- Blockchain

Blockchain is another area which attracts lots of attentions. Maicoin and Gcoin are two major companies in Taiwan with potential bank partners. In addition, TFSB regards blockchain as a crucial foundation of the FinTech industry. Therefore, TFSB 
is planning to set up a national blockchain for all banks. Blockchain contains two major flows, virtual currency flow and information flow. Right now banks are more interested in the aspect of information flow. Four banks will collaborate with Maicoin. Another two banks will collaborate with Gcoin. CTBC bank just announced that they joined the R3 alliance. Therefore, more investment on the blockchain from banks can be expected in the future. T bank's chairman also assigned a taskforce to search for blockchain partners. Because related information is classified, no further information can be revealed in this article. After the on-site visits, $\mathrm{T}$ bank moved on from most candidate companies for several reasons: (a) $\mathrm{T}$ bank would have difficulty developing any unique financial services with these companies (no added value) because they are more like solution vendors; (b) the stock price per share (PE ratio) is too high, and (c) recent analysis indicates that cash and credit cards are still the major payment tools (59 and 58.1\%, respectively) (Market Intelligence \& Consulting Institute 2016). In addition, people can withdraw/wire cash, pay transaction fees, pick up online shopping goods, and buy electronic tickets at any supermarket. With the highest density of supermarkets (over 10,000) in the world (Taiwan Today 2014), payment is convenient in Taiwan. Whether other payment methods can become mainstream is still under observation.

\section{Criteria to select FinTech candidates}

Since banks do not know how to design an innovative financial service using technology and technology companies do not know how to apply their knowledge to finance, $\mathrm{T}$ bank had difficulty identifying qualified candidates. Therefore, due to the limited number of FinTech companies available, they did not identify more than one candidate with potential in the field.

\section{Cooperator or a competitor?}

In the highly competitive market, such as mobile payments or e-wallets, $\mathrm{T}$ bank tended to work as a cooperator rather than a competitor. $\mathrm{T}$ bank regards these products as "must have" services for all banks, which they can purchase from solution vendors. Their goal is to compete with other banks on some unique financial services, such as a P2P platform for SMEs. However, they could not find a company in this area.

\section{Investment}

In Spring 2016, T bank invested in a FinTech company offering smart POS systems based on several strategic considerations. First, retailers currently tend to have more than three devices for different payment options. The smart POS system integrates all kinds of payment options in a small mobile device, which is a very attractive solution for $\mathrm{T}$ bank's customers in retail. Second, $\mathrm{T}$ bank and the FinTech company are complementors; the latter is a major POS system provider for top retailers in Taiwan. As T bank's strength is in SME finance, it can help the FinTech company to expand its market share to small and medium sized retailers. On the other hand, the FinTech company can assist $\mathrm{T}$ bank in expanding its personal finance business, a key goal, especially in issuing credit cards or affinity cards. Finally, the smart POS system 
contains enterprise resource planning (ERP) modules, data analytics (cloud-based), and data visualization (cloud-based) to track retailers' daily business activities. It enables $\mathrm{T}$ bank and the FinTech company to develop innovative financial services and use the POS system as the customer-end interface.

\section{Discussion and evaluation}

\section{Regulations and policies shape FinTech's development}

Government regulations and policies significantly shape an industry's development. The most famous case is the influence of deregulation on the US telecommunications industry in 1982, which resulted in the industry's liberalization (Los Angeles Times 1995). Thus, researchers should track how the series of deregulations will shape Taiwan's FinTech industry development. At the same time, restrictions in the current regulations prevented some overseas FinTech companies from offering their financial services in Taiwan. Based on authors' own observations, the deregulation will continue, though the banking industry will maintain its unique position and high government protection in the future.

\section{Banks, technology companies, and customers are not "FinTech ready"}

Compared to other countries, Taiwan is behind in the revolution of financial digitalization in terms of practical development, customer adoption, and legislation. It seems that Taiwan's banks have been protected for too long. Banks, technology companies, and customers are not "FinTech ready." T bank's Chairman and President also sensed the problem and think that the best way forward is to cultivate collaborative relationships with startups. Therefore, $\mathrm{T}$ bank will set up a maker base and assign a group of $\mathrm{T}$ bank's employees to collaborate with these companies on R\&D. A follow up study of these efforts would be beneficial.

Mobile payment is another example. In 2015-2016, Apple pay, Line pay, WeChat pay, Alipay, and domestic third-party companies introduced assorted innovative payment methods via TSM, HCE, TSP, and QR Code technologies (Financial Supervisory Committee 2016c). However, based on TFSB statistics, credit cards are still the most popular payment method. Most transactions counted as mobile payments were credit card transactions linked with apps. Among these innovative payment technologies, WeChat pay and Alipay attracted a lot of attention in 2015. With a potential 60 billion TWD in spending annually, tourists from China account for about $35 \%$ of annual tourists to Taiwan. Therefore, although only tourists from China can use these two payment options, three banks collaborate with Alipay and four banks collaborate with WeChat pay. These banks are interested in both the Chinese tourists and in crossborder e-commerce transactions and cross-border tuition payments (there are about 8,000 Chinese students studying in Taiwan). The high number of new mobile payment options opens another research topic in terms of how these payment companies/technologies collaborate or compete.

\section{Complex relationships among banks and FinTech companies}

Banks and FinTech companies have complicated relationships. T bank chose to collaborate with other banks on "must have" financial services but compete with them on 
unique technology-based services. The authors assume that other banks have similar strategies because some FinTech companies have refused to remain "xx bank exclusive," especially when their products are more like "must have" services. Therefore, these companies welcome investments from banks and limit their shareholding. On the other hand, startups might like the "exclusive" approach due to the high percentage of investment from a specific bank. However, there is a potential risk that they will not gain contracts with other banks in the future.

\section{Compare Top-down with bottom-up strategies}

$\mathrm{T}$ bank collaborates with other banks on "must have" financial services, such as mobile payments, by collaborating with third-party payment companies so customers can link their bank accounts or credit cards with the third-party wallet or apps. Because these third-party companies aim to cultivate their own payment ecosystem, the authors call this a top-down strategy. On the other hand, the FinTech company $\mathrm{T}$ bank invested in has been working as a solution provider in the retail industry for more than 20 years. It has a solid buyer base and knows buyers' needs. Obviously, the bottom-up strategy is more attractive to $\mathrm{T}$ bank because the collaboration can help the bank expand its current business and discover a new "blue ocean."

\section{Taiwan will have difficulty producing FinTech disruptors in the near future}

Taiwan is not a friendly environment for FinTech startups: firms in this industry face high entrance barriers, high competition, and a market size that is not attractive to new challengers. Second, most financial services are very convenient with low service fees. Therefore, customers might feel that innovative financial services are better than services from existing banks. However, the adoption rate will be slow, just as in credit card versus mobile payments. Third, traditional financial institutions are highly protected by the government. Put another way, the government does not want disruptors because they will damage the foundations of these traditional financial institutions. Therefore, it is unlikely that Taiwan will produce FinTech disruptors in the near future. Instead, almost all FinTech companies will be collaborators aiming to provide solutions for traditional financial institutions.

\section{Conclusion}

The case study reveals the strategic consideration in the process of searching for FinTech investment targets. It seems Taiwan's government aims to cultivate FinTech collaborators rather than disruptors. It is still at the embryonic stage for FinTech industry in Taiwan. Therefore, more studies are desired to observe long-term development in terms of how companies collaborate or compete in specific FinTech areas.

\section{Appendix A}

\section{Regulations related to FinTech investment}

- Information service enterprises are firms whose main business is electronic data processing closely related to the data processing operations of financial institutions; e-commerce trading information processing involving the accounts 
of financial institutions; or research, development, and design of financial information systems to support the business development of financial institutions.

- Financial technology enterprises are firms whose main business is one of the following:

- Using information or network technologies to aid the business development of financial institutions in data gathering, processing, analysis, or supply (e.g., big data, cloud computing, machine learning, etc.).

- Using information or network technologies to improve the efficiency or security of financial service or operating process (e.g., mobile payments, automated investment advisor, blockchain technology, biometrics, etc.).

- Designing or developing other digital or innovative financial services based on information or technology.

- The main business of the aforementioned information service enterprise or financial technology enterprise may not include the manufacture, sale, or leasing of hardware equipment. If such information service enterprise or financial technology enterprise provides hardware equipment, the purpose of the hardware equipment must be congruent with the nature of the business or data mentioned in the preceding paragraph and associated with the design of finance-related applications.

- For information service enterprises or financial technology enterprises that engage in the businesses or activities provided in Point 2 and later section of the preceding point, the portion of its annual operating costs or operating revenue derived from financial enterprises (including financial holding companies, banks, securities firms, insurance companies, and their subsidiaries) and financial services shall make up $51 \%$ or more of its total operating costs or operating revenue. The preceding provision does not apply if the investment of the bank or financial holding company in said information service enterprise or financial technology enterprise is for the purpose of a strategic alliance or enhancing business cooperation, and the bank or financial holding company does not have control or material influence over the enterprise as provided in the Regulations Governing the Preparation of Financial Reports by Public Banks or Regulations Governing the Preparation of Financial Reports by Financial Holding Companies (e.g., shareholding in the enterprise is below 20\%).

- Banks and financial holding companies shall, within 1 month after the end of each fiscal year, report the percentage of annual operating costs and operating revenue of their invested information service enterprise or financial technology enterprise derived from financial enterprises and financial services to the competent authority for recordation. Should the percentage fail to comply with the preceding point, the bank or the financial holding company shall make adjustments to become compliant within 2 years from the year of reporting, and may apply for one extension for a period of 1 year with reasons stated if the adjustment cannot be completed within the prescribed period. If the bank or the financial holding company is still non-compliant past the prescribed and extended period, it shall submit a share disposal plan to the competent authority to reduce its amount of investment or shareholding in the information service enterprise or financial technology enterprise to not more than $5 \%$ of the total paid-in capital or issued and outstanding shares of the enterprise, or make adjustments to become compliant with the latter section of the preceding point. 


\section{Authors' contribution}

J-LH: data collection, data analysis, literature review, and manuscript writing. BL literature review and manuscript writing. Both authors read and approved the final manuscript.

\section{Competing interests}

The authors declare that they have no competing interests.

\section{Author details}

${ }^{1}$ Boise State University, Boise, USA. ${ }^{2}$ Agricultural Bank of China, Sichuan, China.

Received: 2 November 2016 Accepted: 23 November 2016

Published online: 29 November 2016

\section{References}

Accenture (2016) Global Fintech investment growth continues in 2016 driven by Europe and Asia. https://newsroom accenture.com/news/global-fintech-investment-growth-continues-in-2016-driven-by-europe-and-asia-accenturestudy-finds.htm. Accessed 10 Sept 2016.

Benbasat I, Goldstein DK, Mead M (1987) The case research strategy in studies of information systems. MIS Q 11(3):369386

Brandenburger A, Nalebuff B (1996) Co-opetition. Doubleday, New York

Cavaye AL (1996) Case study research: a multi-faceted research approach for IS. Inf Syst J 6(3):227-242

Chiu LT (2011) Retrospect and prospect of financial industry development in Taiwan. Econ Res 11:171-197

Data.Gov.Tw (2015) Financial Supervisory Committee big data project http://data.gov.tw/node/12077. Accessed 30 Sept 2016

Financial Supervisory Commission (2015a) Construct digital finance environments. http://www.fsc.gov.tw/ch/home. jsp?id=96\&parentpath=0,2\&mcustomize=news_view.jsp\&dataserno=201501130003\&toolsflag=Y\&dtable=News. Accessed 21 Sept 2016.

Financial Supervisory Committee (2015b) The act governing electronic payment institutions http://law.fsc.gov.tw/law/ EngLawContent.aspx?Type=C\&id=1802. Accessed 30 Sept 2016.

Financial Supervisory Committee (2015c) Regulations of bank and financial holding company investing FinTech firms http://law.banking.gov.tw/Eng/FLAW/FLAWQRY03.aspx?lsid=FL078705\&keyword=10460003280. Accessed 30 Sept 2016

Financial Supervisory Committee (2015d) Regulations of Industry of Information Service and Industry of Finance Technology Determined by the Competent Authority as Finance Related Industry http://law.banking.gov.tw/Eng/ FLAW/FLAWQRY03.aspx?!sid=FL078705\&keyword=10460003280. Accessed 30 Sept 2016

Financial Supervisory Committee (2016a) Financial technology area http://www.fsc.gov.tw/ch/home.jsp?id= 478\&parentpath $=0,7$. Accessed 30 Sept 2016

Financial Supervisory Committee (2016b) Basic financial data http://www.banking.gov.tw/ch/home.jsp?id= 157\&parentpath $=0,4 \&$ mcustomize $=$ bstatistics_view.jsp\&serno=201105120009. Accessed 30 Sept 2016

Financial Supervisory Committee (2016c) FinTech Development Strategy White Paper http://www.fsc.gov.tw/ch/home. jsp?id=96\&parentpath $=0,2 \&$ mcustomize $=$ news_view.jsp\&dataserno $=201605120002 \& a p l i s t d n=0 u=n e w s, 0 u=$ multisite,ou=chinese,ou=ap_root,o=fsc,c=tw\&dtable=News. Accessed 4 Oct 2016.

Financial Supervisory Committee (2016d) P2P will not set up regulation http://udn.com/news/story/7239/1793803. Accessed 10 Oct 2016

Fintech weekly (nd) Fintech definition. https://www.fintechweekly.com/fintech-definition. Accessed 26 Aug 2016.

Hill C, Lynn L (2003) Producing human services why do agencies collaborate? Public Manage Rev 5(1):63-81

King B (2012) Why banking is no longer somewhere you go but something you do. John Wiley \& Sons, Singapore

Levinson N and Asahi M (1995) Cross-National Alliances and Interorganizational Learning Organizational Dynamics. 24: 50-64.

Los Angeles Times (1995) AT\&T breakup II: highlights in the history of a telecommunications giant. http://articles. latimes.com/1995-09-21/business/fi-48462_1_system-breakup. Accessed 22 Oct 2016.

Market Intelligence \& Consulting Institute (2016) Mobile payment investigation. https://mic.iii.org.tw/micnew/ IndustryObservations_PressRelease02.aspx?sqno=427. Accessed 30 Sept 2016.

Miles MB, Huberman AM (1994) Qualitative data analysis. Sage, Los Angeles

Taiwan Today (2014) Taiwan top for convenience store density. http://taiwantoday.tw/ct.asp?xltem=214462\&ctNode= 2183. Accessed 12 Oct 2016.

Venture Scanner (2016) Financial technology startup landscape trends and insights-04 2016. https://www. venturescanner.com/blog/tags/venture\%20scanner\%20fintech. Accessed 8 Oct 2016.

Wikipedia (nd) Financial technology. https://en.wikipedia.org/wiki/Financial_technology. Accessed 11 Sept 2016. 